\title{
Evaluation of the Hand-To-Face Contact Behaviors of Healthcare Workers and Medical Students in the COVID-19 Pandemic
}

\section{COVID-19 Pandemisinde Sağlık Çalışanları ve Tıp Fakültesi Öğrencilerinin El-Yüz Temas Davranışlarının Değerlendirilmesi}

\author{
Gülsüm Alkan', @Melike Emiroğlu'1, \Şadiye Kübra Tüter Öz1', Onur Ural2, \\ (DŞua Sümer², (Dazlım Aktuğ Demir² \\ 'Selcuk University Faculty of Medicine, Department of Pediatric Infectious Diseases, Konya, Turkey \\ ${ }^{2}$ Selcuk University Faculty of Medicine, Department of Infectious Diseases, Konya, Turkey
}

\begin{abstract}
Background: Respiratory viruses such as severe acute respiratory syndrome coronavirus 2 (SARS-CoV-2), spread via different transmission routes. While the droplet path plays the most important role in transmission, contamination of the mucous membranes with contaminated hands also plays an important role in the spread. Thus, the aim of the present study was to assess the face-touching behaviors of healthcare workers (HCWs) and intern doctors during the coronavirus diseases 2019 (COVID-19) pandemic.

Material and Method: This study was conducted in July 2020 and in the Selcuk University Faculty of Medicine in Konya, Turkey. While 1-hour COVID-19 training was given to healthcare personnel and interns, participants face-touching behavior was monitored through video recording and was tallied with a scoring sheet.

Results: A total of 141 intern doctors, 46 assistant doctors, 14 nurses, 10 associate doctors, and eight staff members participated in the study. On average, each of the participants touched their face a mean of 17.2 times (median: 16; range: $0-45$ ) per hour. Of all the face touches, $85.2 \%$ $(3,228 / 3,787)$ involved contact with a face mask, whereas $14.7 \%(559 / 3,787)$ involved contact with the eye mucosa. Intern doctors touched their faces significantly less often with a mean of 13.7 times per hour $(p<0.001)$, while nurses touched their faces more often with a mean of 28 times per hour $(p<0.001)$. Although nurses touched their eye mucosa more often than interns and assistant doctors $(p<0.001)$, their contact with the face mask was significantly less frequent than that of the other participants $(p<0.001)$.

Conclusions: To date, there are no effective vaccines or antiviral drugs for SARS-CoV-2. For the time being, isolation, social distancing measures, and individuals' protective behaviors are essential for preventing infection. HCWs, medical students, and the broader community should be informed about self-inoculation, which can result from touching one's mucosa or mask with contaminated hands.
\end{abstract}

Keywords: SARS-CoV-2, face-mask, healthcare workers, medical students

\section{Öz}

Amaç: Severe acute respiratory syndrome coronavirus 2 (SARS-CoV-2) gibi solunum yolu virüslerinin farklı bulaşma yolları vardır. Virüsün yayılımında damlacık yolu kadar, ellerle mukozanın kontaminasyonu da önemli rol oynamaktadır. Çalışmamızın amacı, coronavirus disease-19 (COVID-19) salgın sırasında sağlık çalışanları ve intörn doktorların el-yüz temas davranışların değerlendirmektir.

Gereç ve Yöntem: Bu çalışma Temmuz 2020'de ve Selçuk Üniversitesi Tıp Fakültesi Konya, Türkiye'de yapılmıştır. Sağlık personeli ve intörn doktorlara 1 saatlikCOVID-19 ile ilgili eğitim verilirken, katılımcıların el-yüz temas davranışları video kaydı ile izlenerek puanlama tablosu ile değerlendirildi.

Bulgular: Çalışmaya 141 intörn doktor, 46 asistan doktor, 14 hemşire, 10 öğretim üyesi ve sekiz personel katıldı. Katıımcıların her biri yüzlerine saatte ortalama 17,2 kez (medyan: 16; aralık: 0-45) dokunduğu saptandı. Tüm davranışların \% 85,2'si (3,228/3,787) yüz maskesi ile temas,\% 14,7'si $(559 / 3,787)$ göz mukozası ile temastı. İntörn doktorların yüzlerine saatte ortalama 13,7 kez ( $\mathrm{P}<0,001)$, hemşirelerin daha sık; saatte 28 kez dokundukları saptandı ( $\mathrm{P}$ $<0,001)$. Hemşirelerin göz mukozalarına intörn ve asistan doktorlardan daha sık dokunmuş olmalarına rağmen ( $p<0,001$ ), yüz maskesiyle temasları diğer katılımcılara göre anlamlı olarak daha azdı $(p<0,001)$.

Sonuçlar: Bugüne kadar SARS-CoV-2 için etkili aşı veya antiviral ilaç bulunamamıştır. Bu nedenle izolasyon, sosyal mesafe önlemleri ve bireysel koruyucu davranışlar enfeksiyonu önlemek için gereklidir. Sağlık çalışanları, tıp fakültesi öğrencileri ve toplumdaki bireylere; kontamine ellerle mukoza veya maskeye temas sonrasında oluşabilecek virüsle kendini enfekte etme durumu anlatılmalıdır.

Anahtar Kelimeler: SARS-CoV-2, yüz maskesi, sağlık çalışanları, tıp öğrencileri 


\section{INTRODUCTION}

Nosocomial infections with respiratory tract viruses account for the majority of serious nosocomial viral diseases. Effective preventive strategies are based upon early diagnosis and understanding of the mechanisms of transmission. ${ }^{[1]}$ Respiratory viruses spread via different transmission routes, including contact with droplets or droplet nuclei. Hands contaminated with secretions is the most common route of transmission of respiratory infections in health care settings. ${ }^{[2]}$ Infectious disease can result from virus particles being inhaled or coming into contact with the mucosal surface of the nose or eyes. ${ }^{[3,4]} \mathrm{A}$ less well known but common step in the transmission of many respiratory pathogens is self-inoculation. ${ }^{[5]}$ Self-inoculation is a type of contact transmission and acquisition of infection after touching the mucous membranes of the nose, eye, and mouth. ${ }^{[6]}$ Coronavirus disease 2019 (COVID-19) is primarily a respiratory disease caused by severe acute respiratory syndrome corona virus 2 (SARS-CoV-2) and can be transmitted via respiratory droplets, droplet nuclei, and close contact. ${ }^{[7]}$ The incidence of nosocomial infection is expected to be high. ${ }^{[8]}$ Droplet transmission occurs when close personal contact results in the inoculation of the mouth, nose, or conjunctivae. Transmission also occurs via contact with infected surfaces and objects, with the contaminated substance then being mediated through the respiratory mucosa. ${ }^{[9]}$ SARS-CoV-2 may survive for several hours on inanimate surfaces. One of the predominant mechanisms for COVID-19 to be contagious is self-inoculation from contaminated object. ${ }^{[10]}$ Because of the current lack of effective treatment of COVID-19, it is important to obey infection prevention rules for global health. ${ }^{[11]}$

Literature on the frequency of the hand-to-face contact habits of healthcare workers (HCWs) and medical students is limited. Thus, the aim of the present study was to assess the face-touching behaviors of HCWs and intern doctors during the COVID-19 pandemic.

\section{MATERIAL AND METHOD}

In July 2020, HCWs of the Selçuk University of pediatrics department (consisting of associate doctor, assistant doctor, nurses, and staff) who had completed infection control education in the early stages of the pandemic were invited to a lecture for one hour. Intern doctors who had not received prior professional training were also included in the study. During a one-hour lecture, participants face-touching behavior was monitored through video recording and was tailed with a scoring sheet. The participants attended one hour lecture on five separate occasions by profession groups. Initially, they were informed that they would be recorded on video during the training. To eliminate bias, participants were blinded from the aim of the study. The video recording was viewed multiple times by the investigators to note how many times the participants touched their masks and eye mucosa. A standardized scoring sheet was used to count the frequency of face-touching behaviors.
The study was carried out with the permission of Local Ethics Committee of Selçuk University (Permission granted: 2020-12, Decision no: 2020/293).

\section{RESULTS}

A total of 141 intern doctors, 46 assistant doctors, 14 nurses, 10 associate doctors, and eight staff members participated in the study. A total of 219 participants were observed, and 3,787 touches to the face were noted over 60 minutes. On average, each of the participants touched their face a mean of 17.2 times in one hour (median: 16; range: 0-45 times). All participants had face masks. Of all face touches, $85.3 \%$ $(3,228 / 3,787)$ involved contact with a face mask, whereas 14.7 $\%(559 / 3,787)$ involved contact with the eye mucosa.

Intern doctors touched their faces significantly less often than other participants at a mean of 13.7 times per hour (median: 14 ; range: $0-21 ; p<0.001)$. They also touched their face masks less often than assistant doctors $(p<0.001)$ and staff members $(p<0.038)$. Associate doctors touched their faces a mean of 19 times in one hour (median: 22.5; range: 0-27). Their face mask contact frequency was higher than the frequency of their contact with the eye mucosa $(p<0.001)$. Assistant doctors touched their faces a mean of 22.8 times in one hour (median: 24; range: 0-39), whereas staff members touched their faces a mean of 26.7 times in one hour (median: 25; range: 4-41).

Nurses touched their faces more often than the other participants at a mean of 28 times per hour (median: 29; range: $8-44 ; p<0.001)$. Although nurses touched their eye mucosa more often than interns and assistant doctors $(p<0.001)$, their contact with the face masks was significantly less frequent than that of the other participants $(p<0.001)$. Other participants' face mask contact frequencies were higher than the frequencies of contacting the eye mucosa $(p<0.001)$. The frequencies of the face-touching behaviors of the participants are shown in Table 1.

\section{DISCUSSION}

COVID-19 is a new disease, so there is no existing immunity, which has caused it to spread widely and quickly. Hands are considered to be an important source of the spread of infection. Personal protective behaviors and isolation measures are primary and inexpensive methods to prevent the transmission of infection. Therefore, human behavior is central to the transmission of the virus. ${ }^{[2,12]}$ Infection prevention implications include hand hygiene, protection against the inoculation of mucosal surfaces, and disinfection of all frequently touched surfaces. ${ }^{[7]}$

Touching the face is an involuntary behavior for most people. In a healthcare setting, frequent face touching has the theoretical potential to be a mechanism of acquisition and transmission of infection, particularly during a pandemic. Effective interventions are therefore essential to increase adherence to behaviors. ${ }^{[13,14]}$ 


\begin{tabular}{|c|c|c|c|c|c|}
\hline & Associate Doctor & Assistant Doctor & Intern Doctor & Nurses & Staff \\
\hline Number of member (N) & 10 & 46 & 141 & 14 & 8 \\
\hline Male & 7 & 16 & 54 & & 1 \\
\hline Female & 3 & 30 & 87 & 14 & 7 \\
\hline Touches to the Face & 190 & 1049 & 1941 & 393 & 214 \\
\hline Mean: & 19 & 22.8 & 13.7 & 28 & 26.7 \\
\hline Median-Range: & $22.5(0-27)$ & $24(0-39)$ & $14(0-21)$ & $29(8-44)$ & $25(4-41)$ \\
\hline Touches to Mask & 146 & 923 & 1635 & 347 & 177 \\
\hline Mean: & 14.6 & 20 & 11.5 & 3.2 & 22.1 \\
\hline Median-Range: & $17(0-24)$ & $20(0-37)$ & $12(0-20)$ & $3(0-7)$ & $21.5(4-41)$ \\
\hline Touches to Eye Mucosa & 44 & 126 & 306 & 46 & 37 \\
\hline Mean: & 4.4 & 2.7 & 2.1 & 24.7 & 4.6 \\
\hline Median-Range: & $4.5(0-10)$ & $3(0-9)$ & $2(0-9)$ & $25.5(8-42)$ & $4(0-10)$ \\
\hline
\end{tabular}

HCWs wear face masks to protect themselves from patients with respiratory infections. In the community, the wearing of masks by infected individuals is important for reducing contagion. Face masks are commonly used as a nonpharmaceutical intervention to control virus transmission during an influenza pandemic. Specifically, several studies concluded that household use might reduce the transmission of influenza during pandemic. ${ }^{[15,16]}$ Also, face masks are the most cost-effective way to slow viral spread and protect risk groups from infections during the COVID-19 pandemic. Eye, nose, and mouth protection may also provide additional benefits. ${ }^{[2]}$ As a disadvantage, masking may lead to more hand-to-face contact, potentially facilitating self-inoculation. The manipulation of masks has been found to create higher risks of contamination and self-contamination. ${ }^{[12,17]}$

Studies on face touching are limited, as are the rates among HCWs and medical students. In a 2008 study, 10 subjects were each video recorded while performing office-type work, and it was found that they touched their faces an average of 16 times per hour. ${ }^{[18]}$ In another study at the University of Australia, on average, the students touched their faces 23 times each hour. Of all the face touches, $44 \%$ involved contact with a mucous membrane (mouth, nose, or eyes). ${ }^{[2]}$ During the influenza $A$ (H1N1) pandemic, face-touching behavior in the community was observed on average 3.3 times per hour. ${ }^{[19]}$

In our study, on average, each of the participants touched their face a mean of 17.2 times in one hour (median: 16; range: 0-45 times). The frequency was higher than we expected, and most of these cases involved touching the face mask.

During the COVID-19 pandemic, HCWs (including nurses, staff members, assistant doctors, and associate doctors) were trained on infection prevention measures. The intern doctors had returned to the hospital after a long break and had not received professional training about COVID-19 thus far. Even so, intern doctors touched their faces significantly less often than the other participants.

In this study, nurses touched their eye mucosa more often than other participants. Other participants touched their face masks more often than their eye mucosa $(p<0.001)$. Of all the face touches, $85.2 \%$ involved contact with a face mask. It must be considered that wearing a surgical mask may offer an exaggerated, false sense of security and an overvaluing of the protection.

Associate doctors touched their faces a mean of 19 times in one hour, and it was expected that this frequency would be low. Touching the face is a habitual behavior for most people and, as such, it often goes unnoticed, regardless of education level. Habits can be difficult to change even with theoretical knowledge. One study has shown that facial self-touch movements are frequently performed with no awareness and primarily in stressful situations.[20] Although the knowledge level of HCWs is high about infection precautions, the frequency of face contact habits can be associated with stress about COVID-19.

To our knowledge, this is the first study documenting the frequency of face-touching behaviors among HCWs during the COVID-19 pandemic. Our study shows that HCWs touched their faces quite often. Contamination of frequent touch surfaces in healthcare settings can be a potential source of infection transmission. Members of pediatric clinics who are heavily exposed to respiratory viruses may be at increased risk of acquiring an infection. Standard, droplet, and respiratory precautions along with isolation and social distancing measures should be reviewed frequently during a pandemic. In particular, HCWs and medical student awareness must be increased about that fact that face-touching behavior can result in self-inoculation. Public health campaigns and HCWs education should also focus on correcting these unconscious behaviors.

There are several limitations to the present study. First, participants were recruited from only one department, and the number of participants in each profession was not equal. While we did not inform participants that we were observing their face-touching behaviors, they were informed that the training meeting was being video recorded. Thus, this may have changed their behaviors. An observation study conducted with participants during the performance of their duties could provide more accurate results. Therefore, further studies are necessary. 


\section{CONCLUSION}

Currently, there are no effective medications or vaccines available for the treatment or prevention of COVID-19. For this reason, following precautions such as isolation and physical distancing is the best way to protect oneself from the infection. HCWs and the broader community must be educated about COVID-19, including how it is transmitted, and how they can protect themselves. Changing behavior is crucial to prevent transmission in the absence of treatment options.

\section{ETHICAL DECLARATIONS}

Ethics Committee Approval: The study was carried out with the permission of Local Ethics Committee of Selçuk University (Permission granted: 2020-12, Decision no: 2020/293).

Informed Consent: All patients signed the free and informed consent form.

Referee Evaluation Process: Externally peer-reviewed.

Conflict of Interest Statement: The authors have no conflicts of interest to declare.

Financial Disclosure: The authors declared that this study has received no financial support.

Author Contributions: All of the authors declare that they have all participated in the design, execution, and analysis of the paper, and that they have approved the final version.

\section{REFERENCES}

1. Graman PS, Hall CB. Nosocomial viral respiratory infections. Semin Respir Infect 1989;4(4):253-60.

2. Kwok YLA, Gralton J, McLaws M-L. Face touching: a frequent habit that has implications for hand hygiene. Am J Infect Control 2015;43(2):112-4.

3. Kutter JS, Spronken MI, Fraaij PL, Fouchier RA, Herfst S. Transmission routes of respiratory viruses among humans. Curr Opin Virol 2018;28:142-51.

4. Subbarao K, Mahanty S. Respiratory Virus Infections: Understanding COVID-19. Immunity. 2020;52(6):905-9.

5. Elder NC, Sawyer W, Pallerla H, Khaja S, Blacker M. Hand hygiene and face touching in family medicine offices: a Cincinnati Area Research and Improvement Group (CARInG) network study. J Am Board Fam Med 2014;27(3):339-46.

6. Kwok A, McLaws M-L. P157: Face-touching: a frequent habit for selfinoculation of transmissible infections? Antimicrob Resist Infect Control 2013;2(1):P157.

7. Cai J, Sun W, Huang J, Gamber M, Wu J, He G. Indirect Virus Transmission in Cluster of COVID-19 Cases, Wenzhou, China, 2020. Emerg Infect Dis 2020;26(6):1343-5.

8. Zhou Q, Gao Y, Wang X, et al. Nosocomial infections among patients with COVID-19, SARS and MERS: a rapid review and meta-analysis. Ann Transl Med 2020;8(10):629.

9. Sharma A, Tiwari S, Deb MK, Marty JL. Severe acute respiratory syndrome coronavirus-2 (SARS-CoV-2): a global pandemic and treatment strategies. Int J Antimicrob Agents 2020;56(2):106054.

10. Jayaweera M, Perera H, Gunawardana B, Manatunge J. Transmission of COVID-19 virus by droplets and aerosols: A critical review on the unresolved dichotomy. Environ Res 2020;188:109819.

11. Tao J, Song Z, Yang L, Huang C, Feng A, Man X. Emergency management for preventing and controlling nosocomial infection of the 2019 novel coronavirus: implications for the dermatology department. $\mathrm{Br} J$ Dermatol 2020;182:1477-8.
12. West R, Michie S, Rubin GJ, Amlôt R. Applying principles of behaviour change to reduce SARS-CoV-2 transmission. Nat Hum Behav. 2020;4(5):451-9.

13. Belser JA, Gustin KM, Katz JM, Maines TR, Tumpey TM. Influenza virus infectivity and virulence following ocular-only aerosol inoculation of ferrets. J Virol. 2014;88(17):9647-54.

14. Goldmann DA. Transmission of viral respiratory infections in the home. Pediatr Infect Dis J. 2000;19(10):S97-102.

15. Maclntyre CR, Cauchemez S, Dwyer DE, et al. Face mask use and control of respiratory virus transmission in households. Emerg Infect Dis 2009;15(2):233-41.

16. Javid B, Weekes MP, Matheson NJ. Covid-19: should the public wear face masks? BMJ Clin Res 2020;369:1442.

17. Howard J, Huang A, Li Z, et al. Face Mask Against COVID-19: An Evidence Review. Br Med J 2020:1-8.

18. Nicas M, Best D. A study quantifying the hand-to-face contact rate and its potential application to predicting respiratory tract infection. J Occup Environ Hyg 2008;5(6):347-52.

19. Macias AE, de la Torre A, Moreno-Espinosa S, Leal PE, Bourlon MT, RuizPalacios GM. Controlling the novel $A(\mathrm{H} 1 \mathrm{~N} 1)$ influenza virus: don't touch your face! J Hosp Infect 2009;73(3):280-1.

20. Grunwald M, Weiss T, Mueller S, Rall L. EEG changes caused by spontaneous facial self-touch may represent emotion regulating processes and working memory maintenance. Brain Res 2014;1557:111-26. 